\title{
Ammonium assists orthophosphate removal from high-strength wastewaters by natural zeolite
}

Lin Lin ${ }^{\mathrm{a}}$, Chunli Wan ${ }^{\mathrm{a}}$, Duu-Jong Lee ${ }^{*, a, b, c}$, Zhongfang Lei $^{\mathrm{d}}$, Xiang Liu ${ }^{\mathrm{a}}$

${ }^{a}$ Department of Environmental Science and Engineering, Fudan University, 220 Handan Road, Shanghai 200433, China

${ }^{\mathrm{b}}$ Department of Chemical Engineering, National Taiwan University of Science and Technology, Taipei 106, Taiwan

${ }^{\mathrm{c}}$ Department of Chemical Engineering, National Taiwan University, Taipei 106, Taiwan

${ }^{\mathrm{d}}$ Graduate School of Life and Environmental Sciences, University of Tsukuba, 1-1-1 Tennodai, Tsukuba, Ibaraki 305-8572, Japan

*Corresponding author. Tel.: +886 22362 5632; Fax: +886 22362 3040; E-mail:djlee@ ntu.edu.tw (D.-J. Lee).

\section{Abstract}

Nutrients discharge correlates to eutrophication of receiving waters. Phosphorus $(\mathrm{P})$ and nitrogen $(\mathrm{N})$, if recovered from wastewaters, can be applied to land as essential nutrients for plant growth. This study used natural zeolite in batch and continuous tests to simultaneously remove $\mathrm{P}$ and $\mathrm{N}$ from orthophosphate and ammonium-nitrogen laden wastewaters at $\mathrm{pH} 3-11 . \mathrm{In} \mathrm{P}$ only tests, $\mathrm{pH}>9$ is favorable to $\mathrm{P}$ removal. When ammonium was also present, $\mathrm{P}$ removal was significantly enhanced. Ammonium was first adsorbed onto the zeolite via ion exchange to release $\mathrm{Ca}^{2+}$ ions from the zeolite lattice. This ion exchange reaction was independent of the presence of $\mathrm{P}$. Then the released $\mathrm{Ca}^{2+}$ ions precipitated the dissolved phosphate, which was greatly dependent on the concentration of ammonium. Zeolite column could effectively remove $\mathrm{P}$ and $\mathrm{N}$ from fermentation liquor with minimal adsorption of volatile fatty acids. Implications to practice of zeolite treatment were discussed.

Keywords Ammonium; Phosphate; Simultaneous removal; Mechanism; Natural zeolite; Fermentation liquor

\section{Introduction}

Excess discharge of nitrogen $(\mathrm{N})$ and phosphorus $(\mathrm{P})$ to receiving waters yields occurrence of water body eutrophication[1]. Biological nutrient removal (BNR) process is effective to remove nitrogen and phosphorus [2], but it requires expensive supplemented carbon source [3]. Volatile fatty acids (VFAs) produced by anaerobic fermentation of organic wastes are suitable carbon sources for 
1 the BNR process [4]. However, the accompanied high levels of nitrogen $\left(\mathrm{NH}_{4}{ }^{+}-\mathrm{N}>400 \mathrm{mg} \mathrm{l}^{-1}\right)$ and

2 phosphorus $\left(\mathrm{PO}_{4}^{-}-\mathrm{P}>100 \mathrm{mg} \mathrm{l}^{-1}\right)$ in the fermentation liquor have to be effectively removed [5-7].

3 Cost-effective and simple practice with end products recyclable to land use is welcome to remove $\mathrm{N}$ $4 \quad$ and $\mathrm{P}$ in fermentation effluents [8].

5 Zeolite is an aluminosilicate mineral that can be used as ammonium adsorbent at the release of $6 \mathrm{Na}^{+}, \mathrm{Ca}^{2+}, \mathrm{K}^{+}$and/or $\mathrm{Mg}^{2+}$ from the crystal framework [9-15]. For instance, Lin et al. [16] noted the 7 release of $\mathrm{Ca}^{2+}$ ions from their zeolite during ammonium adsorption. Zeolite was also applied for phosphorus removal based on the mechanisms of anion exchange and electrostatic attraction [17-19].

9 Few studies focused on simultaneous removal of N and P by zeolite [20]. Karapınar [21] applied the natural zeolite and dosed calcium ions to remove $\mathrm{N}$ and $\mathrm{P}$ in separated processes.

This study for the first time applied natural zeolite only to simultaneously remove orthophosphate and ammonium-nitrogen from high-strength synthetic wastewater and fermentation effluent. Batch and column tests were adopted to confirm the feasibility of using natural zeolite as a pretreatment unit for making fermentation liquor applicable to subsequent processes such as the BNR process. Experimental conditions with sufficient $\mathrm{N}$ and $\mathrm{P}$ removals were identified. Based on experimental findings, the mechanisms of phosphorus removal by zeolite with the assistance of ammonium were disclosed.

\section{Materials and methods}

\subsection{Materials}

The zeolite used in this study was obtained from Shenshi Mine located in Jinyun, Zhejiang Province, China without modification. After crushing, size sieving to $0.8-1.43 \mathrm{~mm}$, washing with deionized water and air-drying at $105 \pm 1{ }^{\circ} \mathrm{C}$ for $12 \mathrm{~h}$, the prepared zeolite was used in the experiments. The chemical and physical characteristics of the zeolite were reported in Lin et al. [16]. In brief, the natural zeolite has main mineral species of clinoptilolite-Na, heulandite and quartz, with surface area 
1 of $14.33 \mathrm{~m}^{2} \mathrm{~g}^{-1}$ and an ion exchange capacity (IEC) of $0.92 \mathrm{meq} \mathrm{g}^{-1}$.

The feed solutions (N-P mixtures) were prepared by mixing and diluting $4000 \mathrm{mg}^{-\mathrm{N}} \mathrm{l}^{-1}$ of ammonium chloride $\left(\mathrm{NH}_{4} \mathrm{Cl}\right)$ and $1000 \mathrm{mg}-\mathrm{P} \mathrm{l}^{-1}$ of sodium di-hydrogen phosphate $\left(\mathrm{NaH}_{2} \mathrm{PO}_{4}\right)$ stock solutions at prescribed ratio. The $\mathrm{pH}$ of feed solution was adjusted by adding $0.5 \mathrm{M}$ of sodium hydroxide $(\mathrm{NaOH})$ or hydrochloric acid $(\mathrm{HCl})$. All chemicals were of analytical grade. Wastewater was collected from the effluent of the laboratory fermentation reactor of swine manure at $\mathrm{pH} 9.3$ and $35^{\circ} \mathrm{C}$. The fermentation effluent had $1.11 \%$ of total solids (TS), $63.1 \mathrm{mg} \mathrm{l}^{-1}$ of orthophosphate phosphorus $\left(\mathrm{PO}_{4}^{-}-\mathrm{P}\right), 1252 \mathrm{mg} \mathrm{l^{-1 }}$ of ammonium nitrogen $\left(\mathrm{NH}_{4}{ }^{+}-\mathrm{N}\right), 5470 \mathrm{mg} \mathrm{l}^{-1}$ of volatile fatty acids (VFAs) and $2804 \mathrm{mg}-\mathrm{CaCO}_{3} \mathrm{l}^{-1}$ of total alkalinity.

\subsection{Batch experiments}

The batch experiments in $250 \mathrm{ml}$ conical flasks were conducted to consider the effects of $\mathrm{pH}$, ammonium and phosphate concentrations on adsorption/removal performances. The flasks with 100 $\mathrm{ml}$ solution and $10 \mathrm{~g}$ natural zeolite were capped and shaken horizontally at $150 \mathrm{rpm}$ and $25^{\circ} \mathrm{C}$ for $24 \mathrm{~h}$ in a thermostatic shaker (HZQ-X3000, China). Table S1 lists the experimental conditions. The suspension was filtered via $0.45 \mu \mathrm{m}$ filter and the filtrate was analyzed. After tests, the zeolites and precipitate at the flask bottom were collected and washed by deionized water and then freeze-dried (SCIENTZ-12N, China) for 24h. All the above procedures were repeated at least in triplicates with the mean values being reported.

\subsection{Column experiments}

The fixed-bed column experiments were carried out in vertical upflow columns (made of Plexiglas) with $1 \mathrm{~m}$ height and $60 \mathrm{~mm}$ internal diameter at room temperature $\left(20 \pm 1^{\circ} \mathrm{C}\right)$. The column was filled with $300 \mathrm{~g}$ of the natural zeolite at $23 \mathrm{~cm}$ depth. The influent with desired $\mathrm{pH}$ were pumped into the column bottom using the metering pump (MasterFlex L/S, Cole Parmer, USA) at a constant 
1 flow rate of $10 \mathrm{mlmin}^{-1}$, giving $20 \mathrm{~min}$ of contact time. Table S1 lists the other experimental conditions. Effluent from the column was collected and filtered via $0.45 \mu \mathrm{m}$ filter for analysis.

\subsection{Analytical methods}

Determination of $\mathrm{TS}, \mathrm{NH}_{4}-\mathrm{N}, \mathrm{PO}_{4}-\mathrm{P}$ and total alkalinity (titrated to $\mathrm{pH} 4.3$ ) in filtrate were in accordance with the Standard Methods [22]. $\mathrm{pH}$ of suspension was measured using a $\mathrm{pH}$ meter (Multi 340i-WTW, Germany). Concentrations of $\mathrm{Ca}^{2+}$ and $\mathrm{K}^{+}$were measured using atomic absorption spectroscopy (Hitachi-Z 5000, Japan). The concentrations of VFAs $\left(\mathrm{C}_{2}\right.$ to $\left.\mathrm{C}_{5}\right)$ were determined using a gas chromatography (7890A, Agilent, USA) fitted with HP-FFAP (30 m×0.25 $\mathrm{mm} \times 0.25 \mathrm{~mm})$ capillary column and FID detection. The surface morphology and chemical compositions of zeolite and collected precipitates were analyzed by the same methods used in Lin et al. [16].

The removal performance was evaluated by the amount of ammonium or phosphate removed by per unit mass of zeolite, which could be calculated according to $q=V\left(C_{0}-C_{e}\right) / M$, where $q$ is the removal capacity $\left(\mathrm{mg} \mathrm{g}^{-1}\right), C_{0}$ and $C_{e}$ are the initial and equilibrium concentrations of nitrogen or phosphorus ( $\mathrm{mg} \mathrm{l}^{-1}$ ), respectively, $V$ is the feed solution volume (l) and $M$ is the mass of zeolite used (g).

\section{Results}

\subsection{Batch tests}

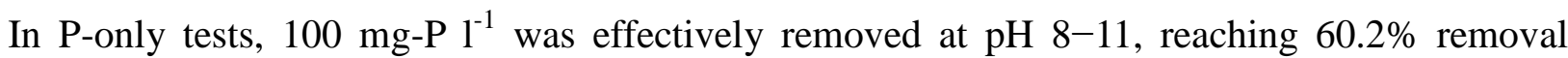
results about the $\mathrm{pH}$-dependent phosphorus removal by zeolites were listed in Table 1. Different chemical compositions of zeolites may be responsible to the noted difference in $\mathrm{pH}$ dependence. In N-P mixtures, the ammonium adsorption capacity onto the tested zeolite used was declined with 
1 increasing $\mathrm{pH}$ at alkaline condition, especially at $\mathrm{pH}>9$. This observation correlates with the findings by Lin et al. [16].The P removal was improved in the presence of ammonium, particularly significant at pH 9-11 (Fig. 1). Restated, the $\mathrm{P}$ removal rate at $\mathrm{pH} 9,10$ and 11 was increased from $41.2 \%, 46.0 \%$ and $60.2 \%$ to $85.8 \%, 99.7 \%$ and $100 \%$, respectively in the presence of $1000 \mathrm{mgl}^{-1}$ ammonium. White precipitates were noted to form during the test. Hence, as Fig. 1 shows, $\mathrm{pH}>9.0$ had adverse effects on ammonium removal but enhanced phosphate removal. At $\mathrm{pH} 9.3$, high removals of both $\mathrm{P}$ and $\mathrm{N}$ were achieved.

Further tests at $\mathrm{pH} 9.3$ were conducted with $100 \mathrm{mg}_{-} \mathrm{P}^{-1}$ and $0-2000 \mathrm{mg}-\mathrm{N} \mathrm{l}^{-1}$ or $1000 \mathrm{mg}-\mathrm{N} \mathrm{l}^{-1}$ and $0-1000 \mathrm{mg}^{-\mathrm{P}^{-1}}$ (Fig. 2). With initial $100 \mathrm{mg}-\mathrm{P}^{-1}$, the $\mathrm{P}$ removal was increased from $43.8 \%$ to $98.9 \%$ as $\mathrm{N}$ was increased to $200 \mathrm{mg}^{-1}$ (Fig. 2a). With up to $200 \mathrm{mg}-\mathrm{N}^{-1}$, all dosed ammonium was removed by the zeolite. As the $\mathrm{N}$ concentration was further increased, the $\mathrm{P}$ removal rate was remained at around $100 \%$, but the $\mathrm{N}$ removal rate was declined, reaching $48 \%$ at $2000 \mathrm{mg}^{-\mathrm{N} \mathrm{l}^{-1}}$ (Fig. 2a).With $1000 \mathrm{mg}-\mathrm{N}^{-1}$, the removal of dosed 20-400 mg-P $\mathrm{l}^{-1}$ was complete; however, the $\mathrm{P}$ removal rate declined at $>600 \mathrm{mg}-\mathrm{P}^{-1}$ (Fig. $\left.2 \mathbf{b}\right)$. The $\mathrm{P}$ removal was $54.2 \%$ when using the mixture of 1000 mg-N $~^{-1}+1000$ mg-P ${ }^{-1}$ (Fig. 2b). In all the tests in Fig. 2b, the $\mathrm{N}$ removal rate was kept around $70 \%$ regardless of the $\mathrm{P}$ concentration.

As noted in the above tests, the tested zeolite removed limited quantities of dosed $\mathrm{P}$, reaching $0.607 \mathrm{mg} \mathrm{g}^{-1}$ at $\mathrm{pH}$ 11. At $\mathrm{pH} 9.3$, the $\mathrm{N}$ removal depended only on $\mathrm{N}$ concentration rather than on $\mathrm{P}$ concentration. The adsorption isotherm at $25^{\circ} \mathrm{C}$ resembled a Langmuir curve with an abrupt increase in adsorption quantity at low $\mathrm{N}$ concentration regime (Fig. S1). Conversely, the $\mathrm{P}$ removal was significantly affected by the $\mathrm{N}$ concentration.

Ammonium removal by zeolite was proposed as monolayer molecular adsorption with zeolite $[13,23]$. Rate-limiting step for P removal with zeolite was claimed as the electron exchange between phosphorus and the zeolite surface [19]. In the N-P mixture both ammonium and phosphate were mostly removed in $3 \mathrm{hr}$. (Fig 3(a)). Both kinetic data of $\mathrm{N}$ and $\mathrm{P}$ removals well fitted the 
1 intra-particle diffusion model with three-linear regions (Fig. 3(b)) $[4,24]$ using

$2 \quad q_{t}=k_{d} t^{1 / 2}+C$

3 where $k_{d}$ is the coefficient of intra-particle diffusion $\left(\mathrm{mg} \mathrm{g}^{-1} \cdot \mathrm{min}^{-1 / 2}\right)$. Multi-linear plots indicated that

4 three steps took place in $\mathrm{N}$ and $\mathrm{P}$ removal processes: firstly, $\mathrm{NH}_{4}{ }^{+}$and $\mathrm{PO}_{4}{ }^{3-}$ diffused from the

5 solution to the external surface of adsorbent; the second step was gradual adsorption stage on the

6 external and internal surface of zeolite, which was followed by the final equilibrium stage. The

7 best-fit results were given in Table 2 . The $k_{d 2}$ and $k_{d 3}$ values for $\mathrm{P}$ were both much lower than those

8 for $\mathrm{N}$, suggesting that adsorption phase of $\mathrm{P}$ was very poor in the present zeolite [24], and $\mathrm{PO}_{4}{ }^{3-}$

9 removal occurred most probably in the external boundary layer film of liquor surrounding the zeolite 10 particles.

\subsection{Column tests}

The zeolite column was used to treat the synthetic wastewater with $1163 \mathrm{mg}-\mathrm{N}^{-1}$ and $70 \mathrm{mg}-\mathrm{P}$

$\mathrm{l}^{-1}$ at $\mathrm{pH}$ 9.30. At the initial $80 \mathrm{~min}$, both $\mathrm{N}$ and $\mathrm{P}$ were completely removed. Breakthrough occurred at $100 \mathrm{~min}$. Effluent $\mathrm{N}$ concentration reached $50 \%$ of the influent at $160 \mathrm{~min}$, while the $\mathrm{P}$ concentration was increased slowly, reaching $20 \mathrm{mg}^{-\mathrm{P}} \mathrm{l}^{-1}$ at $360 \mathrm{~min}(\mathbf{F i g}$. 4a). Since the contact time was only $20 \mathrm{~min}$, a worse performance for continuous tests was expected compared with the batch tests lasting for $24 \mathrm{~h}$.

The result by using the zeolite column to treat real wastewater at $20 \mathrm{~min}$ of contact time was shown in Fig. 4b. With feeding solution of $63.1 \mathrm{mg}-\mathrm{P} \mathrm{l}^{-1}, 1252 \mathrm{mg}-\mathrm{N} \mathrm{l}^{-1}, 2000 \mathrm{mg}-\mathrm{CaCO}_{3} \mathrm{l}^{-1}$, and $215470 \mathrm{mg}^{2}$ VFA $\mathrm{l}^{-1}$, in the first $60 \mathrm{~min}$ of column test, all $\mathrm{N}$ and $>90 \%$ of $\mathrm{P}$ were removed with unchanged VFA and TA levels. Breakthrough of $\mathrm{N}$ and $\mathrm{P}$ occurred since $80 \mathrm{~min}$. Meanwhile, the TA level was gradually increased. At $360 \mathrm{~min}$, the TA in effluent was increased from $2000 \mathrm{mg}$ to 2800 $\mathrm{mg}^{-1}$. The tested zeolite had no adsorption on the VFAs in the suspensions. 


\section{Discussion}

\subsection{Removal mechanisms}

Soluble inorganic $\mathrm{P}$ can be present in four different chemical forms: $\mathrm{H}_{3} \mathrm{PO}_{4}$ at $\mathrm{pH}<2 ; \mathrm{H}_{2} \mathrm{PO}_{4}{ }^{-}$at pH 3-6.5; $\mathrm{HPO}_{4}{ }^{2-}$ at $\mathrm{pH} 7.5-12 ; \mathrm{PO}_{4}{ }^{3-}$ at $\mathrm{pH}>12$ [25]. As listed in Table 1, different zeolites can have very different $\mathrm{P}$ removal capacities, likely due to distinct dominant mechanisms. The increased removal rates of $\mathrm{P}$ at high $\mathrm{pH}$ in Fig. 1 suggested that neither anion exchange nor electrostatic attraction control the present $\mathrm{P}$ removal since excess $\mathrm{OH}^{-}$at $\mathrm{pH} 11$ did not compete with $\mathrm{HPO}_{4}{ }^{2-}$ from adsorption sites [26].

The SEM images revealed that after wastewater treatment the surface of zeolite was converted from flat and smooth to irregular and rough, with precipitate forming on the surface (Figs. S2 in the Supplementary Materials). The EDS results revealed that the precipitate had a composition of O (55.8\%), $\mathrm{Ca}(25.5 \%), \mathrm{P}(15.3 \%), \mathrm{Mg}(2.73 \%), \mathrm{Na}(0.67 \%)$ and $\mathrm{K}(0.02 \%)$, indicating the precipitate is calcium phosphate precipitate, correlating with the chemical precipitation works reported by Kõiv et al.[27]. Based on the previous EDS analysis [16], Ca is the secondary primary cation component (next to $\mathrm{Al}$ ) in the crystal framework of natural zeolite amounting for $2.09 \%$ of total atoms weight, which could be replaced by $\mathrm{Na}^{+}$and $\mathrm{NH}_{4}{ }^{+}$in the solution easily [12,28]. Just as shown in Table 3 , at initial $\mathrm{pH} 4.0$ condition the co-presence of ammonium promoted $530.7 \mathrm{mg}^{-1}$ of more $\mathrm{Ca}^{2+}$ to release, while at initial $\mathrm{pH} 9.0$ condition, concentrations of both $\mathrm{Ca}^{2+}$ and $\mathrm{PO}_{4}{ }^{3-}$ decreased significantly. That was probably because at alkaline condition, $\mathrm{Ca}^{2+}, \mathrm{OH}^{-}$and $\mathrm{PO}_{4}{ }^{3-}$ (in the form of $\mathrm{HPO}_{4}{ }^{2-}$ ) could react chemically to form hydroxyapatite (HAP) which has the highest thermodynamic stability among various calcium phosphate precipitates [29]. The following mechanisms were supposed to occur in the present N-P-zeolite system:

Zeolite- $\mathrm{Ca}^{2+}+2 \mathrm{Na}^{+} \rightarrow \mathrm{Ze}-2 \mathrm{Na}^{+}+\mathrm{Ca}^{2+}$

Zeolite- $\mathrm{Ca}^{2}+2 \mathrm{NH}_{4}{ }^{+} \rightarrow \mathrm{Ze}-2 \mathrm{NH}_{4}{ }^{+}+\mathrm{Ca}^{2+}$

$5 \mathrm{Ca}^{2+}+3 \mathrm{HPO}_{4}{ }^{2-}+4 \mathrm{OH}^{-} \rightarrow \mathrm{Ca}_{5} \mathrm{OH}\left(\mathrm{PO}_{4}\right)_{3} \downarrow+3 \mathrm{H}_{2} \mathrm{O}$ 
1 Restated, the $\mathrm{Ca}^{2+}$ on zeolite was exchanged with sodium and ammonium ions in the studied system. Reactions (2) and (3) are independent of the concentration of phosphorus (Fig. 2b). Phosphorus was removed by precipitation with the freed $\mathrm{Ca}^{2+}$. In the P-only tests, limited quantities of $\mathrm{Ca}^{2+}$ were released by the $\mathrm{Na}^{+}$, so limited quantities of phosphorus was removed (Fig. 2a). The reaction eq. (4) can occur at $\mathrm{pH}>7$, and will be at favorable rate only at $\mathrm{pH}>9$ [30], which interprets that the excess removal of $\mathrm{P}$ at $\mathrm{pH}>9$ (Fig. 2) is a kinetics-controlled rather than a thermodynamics-controlled process.

\subsection{Implications to practice}

Comparing the results from column tests with synthetic wastewater and fermentation effluent, the studied zeolite removed $15.6 \%$ and $39.4 \%$ less ammonium and phosphate, respectively. This occurrence should be attributable to the role of competing ions on adsorption sites for $\mathrm{N}$ removal and on precipitation species for $\mathrm{P}$ removal.

Based on the stoichiometric relationship in Eqs. (3) and (4), to remove 1 mole of P needs 3.3 moles of N. At pH 9.3 about $700 \mathrm{mg} \mathrm{l}^{-1}$ of ammonium ion $\left(=50 \mathrm{mmol} \mathrm{l}^{-1}\right)$ were removed by $10 \mathrm{~g}$ of the studied zeolite (Fig. 2a), while the $\mathrm{Ca}^{2+}$ concentrations in the suspensions were noted at $462 \mathrm{mg}$ $\mathrm{l}^{-1}$. Hence, at $\mathrm{pH} 9.3$ if assuming $25 \mathrm{mmol} \mathrm{l}^{-1}$ of $\mathrm{Ca}^{2+}$ was released accompanied with the adsorption of $50 \mathrm{mmol} \mathrm{l}^{-1}$ ammonium ions, considering the corresponding removal of $\mathrm{P}$ to be $78.1 \mathrm{mg} \mathrm{l}^{-1}(=2.52$ mmol $\left.l^{-1}\right)$, yielding a molar ratio of $\left(\mathrm{NH}_{4}{ }^{+}\right.$assumption $) /(\mathrm{P}$ removal $)=(20 / 1)$, about six times to that by stoichiometry (3/3/1). The $\mathrm{Ca}^{2+}$ ions can form precipitates with carbonate and other anions, which account for the excess ammonium adsorption noted in these tests.

As $\mathrm{K}^{+}$is preferred than $\mathrm{NH}_{4}^{+}$in ion exchange for natural zeolite[31], the $797 \mathrm{mg} \mathrm{l}^{-1}$ of $\mathrm{K}$ in the fermentation liquor should significantly inhibit ammonium adsorption by zeolite. On the other hand, alkalinity was produced in fermentation [32], with the formed $\mathrm{CO}_{3}{ }^{2-}$ being a strong competitor to phosphate for precipitation[30].Therefore, the $\mathrm{N}+\mathrm{P}$ wastewaters with few competing cations such as 
$1 \mathrm{~K}^{+}$or $\mathrm{Na}^{+}$for ion exchange reaction and competing anions such as $\mathrm{CO}_{3}{ }^{2-}$ for precipitation reaction can reach simultaneous $\mathrm{N}$ and $\mathrm{P}$ removal by zeolite treatment. When $\mathrm{N}+\mathrm{P}$ feed has high levels of $\mathrm{K}^{+}$

3 or $\mathrm{Na}^{+}$, high $\mathrm{P}$ removal should be achieved with poor $\mathrm{N}$ removal performance. With $\mathrm{N}+\mathrm{P}$ feed of

4 high levels of $\mathrm{CO}_{3}{ }^{2-}$, $\mathrm{P}$ removal would be suppressed. Manipulation of the removal performances of

$5 \mathrm{~N}, \mathrm{P}$ and other ions can be easily made by adjusting the dose amount of zeolite.

6 The studied zeolite did not adsorb VFA, so the produced effluent with low concentrations of $\mathrm{N}$ and $\mathrm{P}$ can be utilized as supplemented carbon sources for BNR treatment process [5,33]. The adsorbed zeolite and precipitate are enriched in $\mathrm{N}$ and $\mathrm{P}$ hence can be used as agricultural fertilizers. The zeolite treatment is environmental friendly and cost effective for simultaneous removal of $\mathrm{N}$ and 10 P from wastewaters.

\section{Conclusions}

This study applied natural zeolite for simultaneous removal of $\mathrm{P}$ and $\mathrm{N}$ from wastewaters. At $\mathrm{pH}$

9.3, recoveries of $\mathrm{P}$ and $\mathrm{N}$ were high. A two-step mechanism was proposed to interpret the experimental data: ammonium was adsorbed to zeolite by releasing $\mathrm{Ca}^{2+}$ ion to solution, then the released $\mathrm{Ca}^{2+}$ ions formed precipitate with phosphate for removal. To reach high levels of simultaneous removal of $\mathrm{P}$ and $\mathrm{N}$, an $\mathrm{N} / \mathrm{P}$ ratio $>3.3$ was proposed as the criterion. Fermentation liquor after zeolite treatment can provide carbon sources to BNR process and the used zeolite can be used as green fertilizer.

\section{REFERNECES}

[1] Q.W. Min, Y.L. Jiao. Effects of agricultural non-point source pollution on eutrophication of water body and its control measure. Acta Ecologica Sinica, 3 (2002) 001.

[2] A. Hedström. Ion exchange of ammonium in zeolites: a literature review. Journal of Environmental Engineering, 127 (2001) 673-681. 
[3] D. Karadag, Y. Koc, M. Turan, B. Armagan. Removal of ammonium ion from aqueous solution using natural Turkish clinoptilolite. Journal of Hazardous Materials, 136 (2006) 604-609.

[4] R. Moser-Engeler, K.M. Udert, D. Wild, H. Siegrist. Products from primary sludge fermentation and their suitability for nutrient removal. Water Science and Technology, 38 (1998) 265-273.

[5]Y. Chen, S. Jiang, H. Yuan, Q. Zhou, G. Gu. Hydrolysis and acidification of waste activated sludge at different pHs. Water Research, 41 (2007) 683-689.

[6] X.R. Kang, G.M. Zhang, L. Chen, W.Y. Dong, W.D. Tian. Effect of Initial pH adjustment on hydrolysis and acidification of sludge by ultrasonic pretreatment. Industrial \& Engineering Chemistry Research, 50 (2011) 12372-12378.

[7] L. Lin, C. Wan, X. Liu, D.J. Lee, Z. Lei, Y. Zhang, J.H. Tay. Effect of initial pH on mesophilic hydrolysis and acidification of swine manure. Bioresource Technology, 136 (2013) 302-308.

[8] A. Terada, K. Hibiya, J. Nagai, S. Tsuneda, A. Hirata. Nitrogen removal characteristics and biofilm analysis of a membrane-aerated biofilm reactor applicable to high-strength nitrogenous wastewater treatment. Journal of Bioscience and Bioengineering, 95 (2003) 170-178.

[9] G.V. Tsitsishvili, T.G. Andronikashvili, G.N. Kirov, L.D. Filizova. Natural zeolites. Ellis Horwood New York, 1992.

[10] J.W. Choe, J.H. Kim, T.H. Chung. Effect of competing cation on ammonium ion exchange: Characteristics of zeolite in a bi-solute system. Journal of Environmental Science and Health Part A- Toxic/Hazardous Substances \& Environmental Engineering, 34 (1999) 1553-1567.

[11] H.M. Huang, X.M. Xiao, B. Yan, L.P. Yang. Ammonium removal from aqueous solutions by using natural Chinese (Chende) zeolite as adsorbent. Journal of Hazardous Materials, 175 (2010) 247-252.

[12] V.J. Inglezakis. The concept of "capacity" in zeolite ion-exchange systems. Journal of Colloid and Interface Science, 281 (2005) 68-79.

[13] M. Sprynskyy, M. Lebedynets, R. Zbytniewski, J. Namiesnik, B. Buszewski. Ammonium 
removal from aqueous solution by natural zeolite, Transcarpathian mordenite, kinetics, equilibrium and column tests. Separation and Purification Technology, 46 (2005) 155-160.

[14] Y.F. Wang, F. Lin, W.Q. Pang. Ammonium exchange in aqueous solution using Chinese natural clinoptilolite and modified zeolite. Journal of Hazardous Materials, 142 (2007) 160-164.

[15] G. Markou, D. Vandamme, K. Muylaert. Using natural zeolite for ammonia adsorption from wastewater and as nitrogen releaser for the cultivation of Arthrospira platensis. Bioresource Technology, 155 (2014)373-378.

[16] L. Lin, Z. Lei, L.Wang, X. Liu, Y. Zhang, C. Wan, D.-J. Lee, J.H. Tay. Adsorption mechanisms of high-levels of ammonium onto natural and NaCl-modified zeolites. Separation and Purification Technology, 103 (2013) 15-20.

[17] T.H. Dao. Competitive anion sorption effects on dairy wastewater dissolved phosphorus extraction with zeolite-based sorbents. Journal of Food Agriculture and Environment, 1 (2003) 263-269.

[18] N.S. Dionisiou, T. Matsi, N.D. Misopolinos. Phosphorus Adsorption-Desorption on a Surfactant-Modified Natural Zeolite: A Laboratory Study. Water, Air, \& Soil Pollution, 224 (2013) 1-10.

[19] C. Jiang, L. Jia, Y. He, B. Zhang, G. Kirumba, J. Xie. Adsorptive removal of phosphorus from aqueous solution using sponge iron and zeolite. Journal of Colloid and Interface Science, 402 (2013) 246-252.

[20] D. Wu, B. Zhang, C. Li, Z. Zhang, H. Kong. Simultaneous removal of ammonium and phosphate by zeolite synthesized from fly ash as influenced by salt treatment. Journal of Colloid and Interface Science, 304 (2006) 300-306.

[21] N. Karapınar. Application of natural zeolite for phosphorus and ammonium removal from aqueous solutions. Journal of Hazardous Materials, 170 (2009) 1186-1191.

[22] APHA. Standard Methods for the Examination of Water and Wastewater. American Public 
Health Association: Washington, DC, 2005.

[23] Q. Du, S.J. Liu, Z.H. Cao, Y.Q. Wang. Ammonia removal from aqueous solution using natural Chinese clinoptilolite.Separation and Purification Technology, 44 (2005) 229-234.

[24] M.S. Onyango, D. Kuchar, M. Kubota, H. Matsuda. Adsorptive removal of phosphate ions from aqueous solution using synthetic zeolite. Industrial \&Engineering Chemistry Research, 46 (2007) 894-900.

[25] S.L. Tisdale, W.L. Nelson, J.D. Beaton. Soil fertility and fertilizers. Collier Macmillan Publishers, 1985.

[26] K. Chen, K. Zhao, H. Zhang, Q. Sun, Z. Wu, Y. Zhou, Y. Zhong, F. Ke. Phosphorus removal from aqueous solutions using a synthesized adsorbent prepared from mineralized refuse and sewage sludge. Environmental Technology, 34 (2013) 1-8.

[27] M. Kõiv, M. Liira, U. Mander, R. Mõtlep, C. Vohla, K. Kirsimäe. Phosphorus removal using Ca-rich hydrated oil shale ash as filter material-the effect of different phosphorus loadings and wastewater compositions. Water Research, 44 (2010) 5232-5239.

[28] Y. Watanabe, H. Yamada, H. Kokusen, J. Tanaka, Y. Moriyoshi, Y. Komatsu. Ion exchange behavior of natural zeolites in distilled water, hydrochloric acid, and ammonium chloride solution. Separation Science and Technology, 38 (2003) 1519-1532.

[29] M. Van Kemenade, P.L. De Bruyn. A kinetic study of precipitation from supersaturated calcium phosphate solutions. Journal of Colloid and Interface Science, 118 (1987) 564-585.

[30] M.B. Vanotti, A.A. Szogi, P.G. Hunt. Extraction of soluble phosphorus from swine wastewater. Transactions of the ASAE, 46 (2003) 1665-1674.

[31] L.L. Ames. The cation sieve properties of clinoptilolite. American Mineralogist, 45 (1960) 689-700.

[32] S.G. Sommer, S. Husted. The chemical buffer system in raw and digested animal slurry. The Journal of Agricultural Science, 124 (1995) 45-53. 
1 [33] X. Chen, K. Wendell, J. Zhu, J. Li, X. Yu, Z. Zhang. Synthesis of nano-zeolite from coal fly ash and its potential for nutrient sequestration from anaerobically digested swine wastewater. Bioresource Technology, 110 (2012) 79-85.

4 [34] S. Meng, Y. Li, T. Zhang, J. Chen, P. Xu, C. Song, L. Fan, L. Qiu. Influences of environmental 5 factors on lanthanum/aluminum-modified zeolite adsorbent (La/Al-ZA) for phosphorus adsorption from wastewater. Water, Air, \& Soil Pollution, 224 (2013) 1-8. 


\section{FIGURE CAPTIONS}

Figure 1.Effects of $\mathrm{pH}$ on ammonium and phosphate removal rates by the natural zeolite in P-only and N-P mix, respectively.

Figure 2(a). Effects of initial ammonium concentration on ammonium and phosphate removal rates by the natural zeolite at initial $100 \mathrm{mg}-\mathrm{P}^{-1}$ condition.

Figure 2(b). Effects of initial phosphate concentration on ammonium and phosphate removal rates by the natural zeolite at initial $1000 \mathrm{mg}-\mathrm{N}^{-1}$ condition.

Figure 3(a). Effects of contact time on ammonium and phosphate concentration by the natural zeolite at initial $1000 \mathrm{mg}_{-} \mathrm{N}^{-1}$ and $100 \mathrm{mg}-\mathrm{P}^{-1}$ condition.

Figure 3(b). Kinetic plots of intra-particle diffusion model for ammonium and phosphate removals by the natural zeolite at initial $1000 \mathrm{mg}^{-\mathrm{N}^{-1}}$ and $100 \mathrm{mg}^{-} \mathrm{P} \mathrm{l}^{-1}$ condition.

Figure 4(a). Breakthrough of ammonium and phosphate removals by the natural zeolite in column tests treating N-P mix.

Figure 4(b). Breakthrough of ammonium, phosphate, total alkalinity and VFAs removals by the natural zeolite in column tests treating the fermentation liquor. 
Table 1. Zeolites used as the adsorbents for phosphate removal.

\begin{tabular}{|c|c|c|c|c|c|}
\hline Material & $q_{t}\left(\mathrm{mgg}^{-1}\right)$ & $\mathrm{pH}$ & Effect & Removal mechanism proposed & Reference \\
\hline HDTA-Br modified zeolite & 0.194 & $4.2,10.4$ & $\mathrm{pH}$ increased, removal increased & Anion exchange \& electrostatic attraction & {$[18]$} \\
\hline Zeolite & 0.71 & $3.0-10.0$ & $\mathrm{pH}$ increased, removal decreased & Electrostatic attraction & [26] \\
\hline HUD synthetic zeolite & 79.40 & $2.5-10.0$ & pH increased, removal decreased & $\begin{array}{l}\text { Chemical interaction \& electrostatic } \\
\text { attraction }\end{array}$ & [24] \\
\hline La/Al-modified zeolite & 2.43 & $2.0-12.0$ & Favorable range: $4.0-8.0$ & Electrostatic attraction & {$[34]$} \\
\hline Synthesized zeolite-Al & 54.17 & 5.71 & NA & Chemical interaction\& ligand exchange. & {$[20]$} \\
\hline Synthesized zeolite-Ca & 30.46 & 6.78 & NA & Chemical interaction & [20] \\
\hline Zeolite & 0.30 & NA & NA & $\begin{array}{l}\text { Electrostatic attraction or } \\
\text { anion-exchange. }\end{array}$ & [19] \\
\hline
\end{tabular}


Table 2. Kinetic parameters for ammonium and phosphate removal using the natural zeolite.

\begin{tabular}{llll}
\hline Adsorption stage & Parameters & $\mathrm{NH}_{4}-\mathrm{N}$ & $\mathrm{PO}_{4}-\mathrm{P}$ \\
\hline \multirow{2}{*}{ First stage } & $k_{d 1}$ & 1.331 & 0.144 \\
& $\mathrm{R}^{2}$ & 0.903 & 0.990 \\
Second stage & $k_{d 2}$ & 0.496 & 0.034 \\
Third stage & $\mathrm{R}^{2}$ & 0.968 & 0.949 \\
& $k_{d 3}$ & 0.023 & $7.217 \times 10^{-5}$ \\
& $\mathrm{R}^{2}$ & 0.877 & 0.640 \\
\hline
\end{tabular}


Table 3. Concentrations of ions in batch experiments before and after zeolite adsorption.

\begin{tabular}{lllllllll} 
Solution type & Initial $\mathrm{pH}$ & $\begin{array}{l}\text { Before/after } \\
\text { adsorption }\end{array}$ & \multicolumn{2}{l}{ Ion concentration $\left(\mathrm{mg} \mathrm{l}^{-1}\right)$} \\
\cline { 3 - 8 } & & $\mathrm{NH}_{4}{ }^{+}-\mathrm{N}$ & $\mathrm{PO}_{4}{ }^{3-}-\mathrm{P}$ & $\mathrm{Ca}^{2+}$ & $\mathrm{Na}^{+}$ & $\mathrm{Mg}^{2+}$ & $\mathrm{K}^{+}$ \\
\hline $\mathrm{P}$ & 4.0 & before & 0 & 101 & 0 & 90.0 & 0 & 0 \\
& & after & 0 & 94.4 & 65.3 & 43.6 & 1.3 & 3.1 \\
& \multirow{2}{*}{9.0} & before & 0 & 102 & 0 & 123 & 0 & 0 \\
& & after & 0 & 59.8 & 2.3 & 11.2 & 0.3 & 0.2 \\
N-P mixture & 4.0 & before & 990 & 102 & 0 & 75.4 & 0 & 0 \\
& \multirow{2}{*}{9.0} & after & 285 & 92.6 & 597 & 545 & 7.1 & 58.6 \\
& & before & 981 & 102 & 0 & 234 & 0 & 0 \\
& & after & 281 & 14.5 & 462 & 662 & 7.3 & 64.5 \\
\hline
\end{tabular}




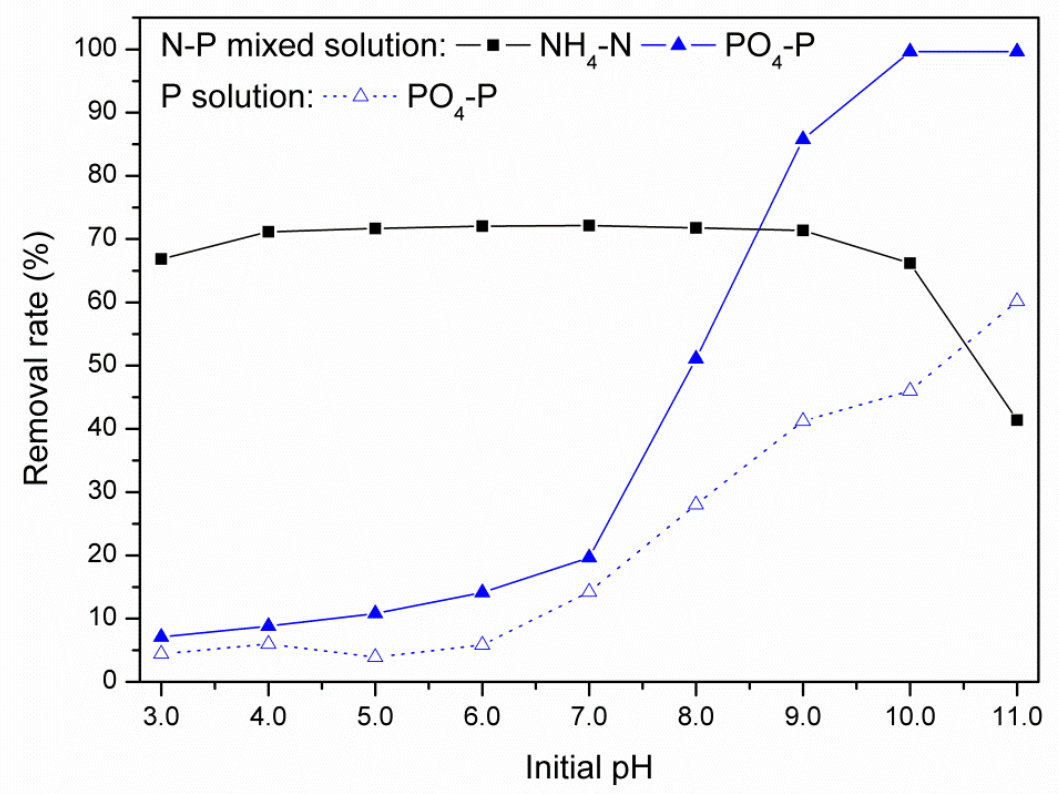

Figure 1.Effects of $\mathrm{pH}$ on ammonium and phosphate removal rates by the natural zeolite in P-only and N-P mix, respectively. 


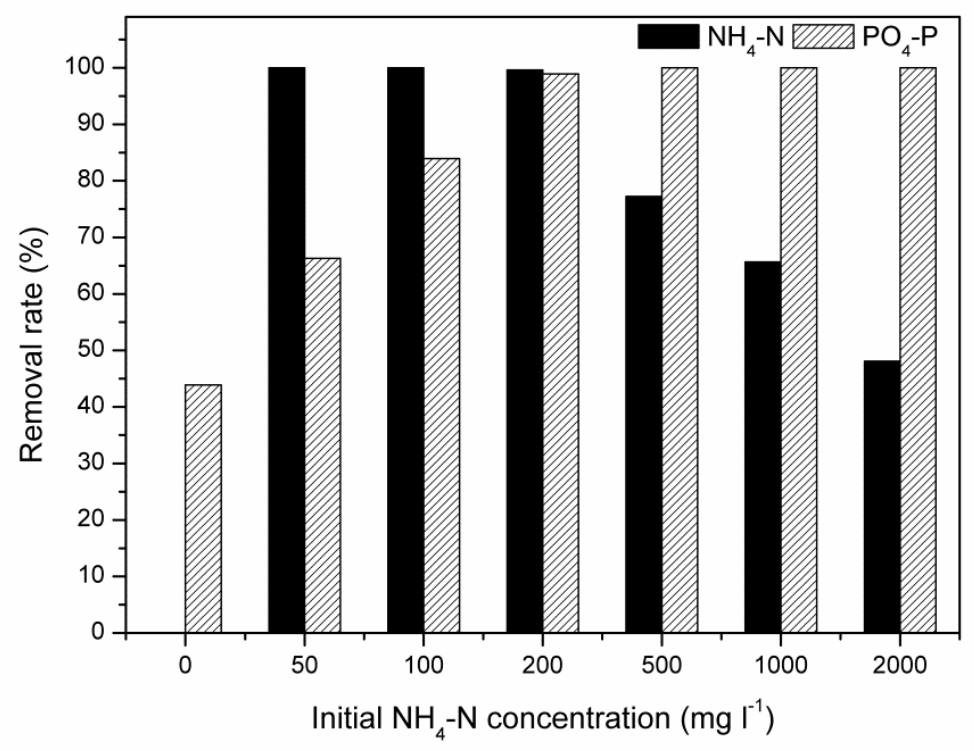

Figure 2(a). Effects of initial ammonium concentration on ammonium and phosphate removal rates by the natural zeolite at initial $100 \mathrm{mg}-\mathrm{P}^{-1}$ condition.

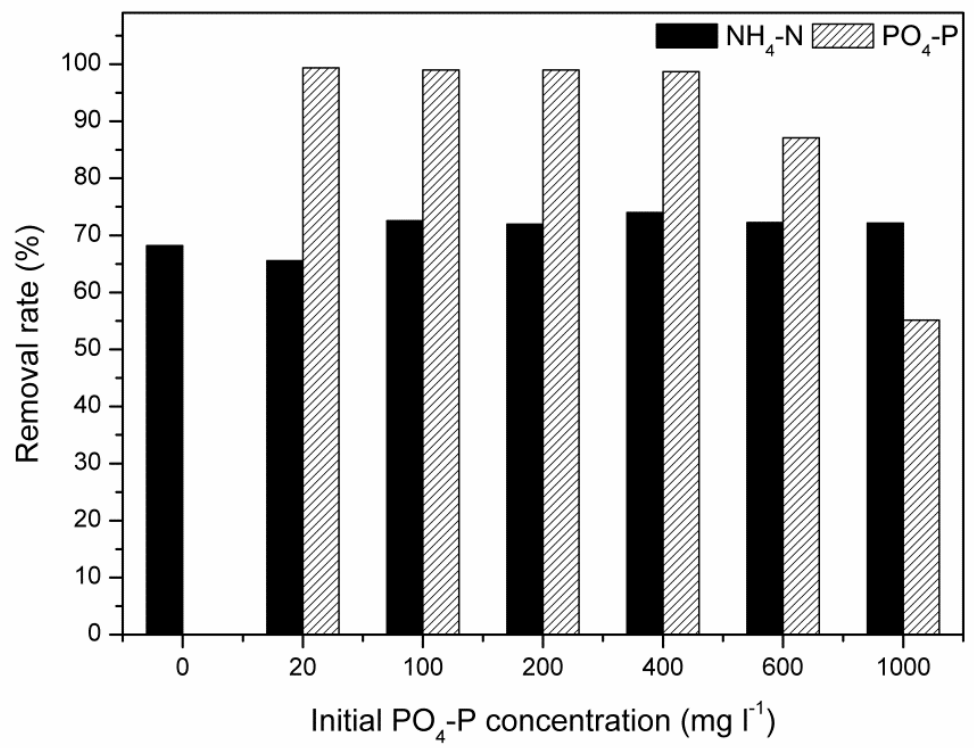

Figure 2(b). Effects of initial phosphate concentration on ammonium and phosphate removal rates by the natural zeolite at initial $1000 \mathrm{mg}-\mathrm{N}^{-1}$ condition. 


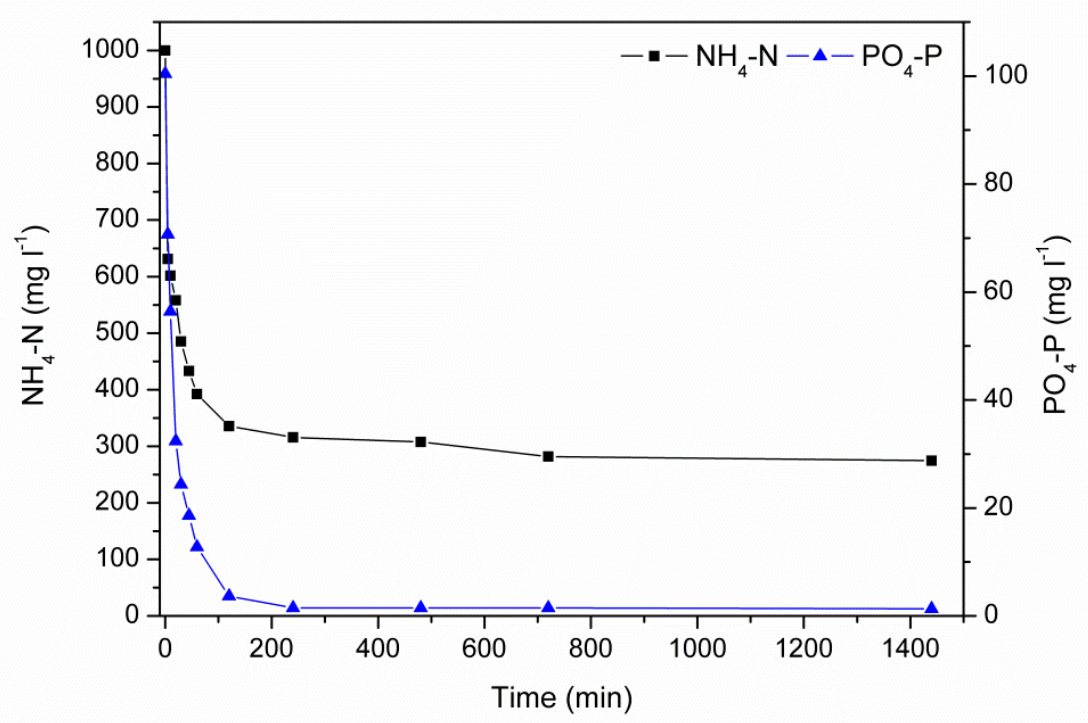

Figure 3(a). Effects of contact time on ammonium and phosphate concentration by the natural zeolite at initial $1000 \mathrm{mg}-\mathrm{N}^{-1}$ and $100 \mathrm{mg}-\mathrm{P} \mathrm{l}^{-1}$ condition.

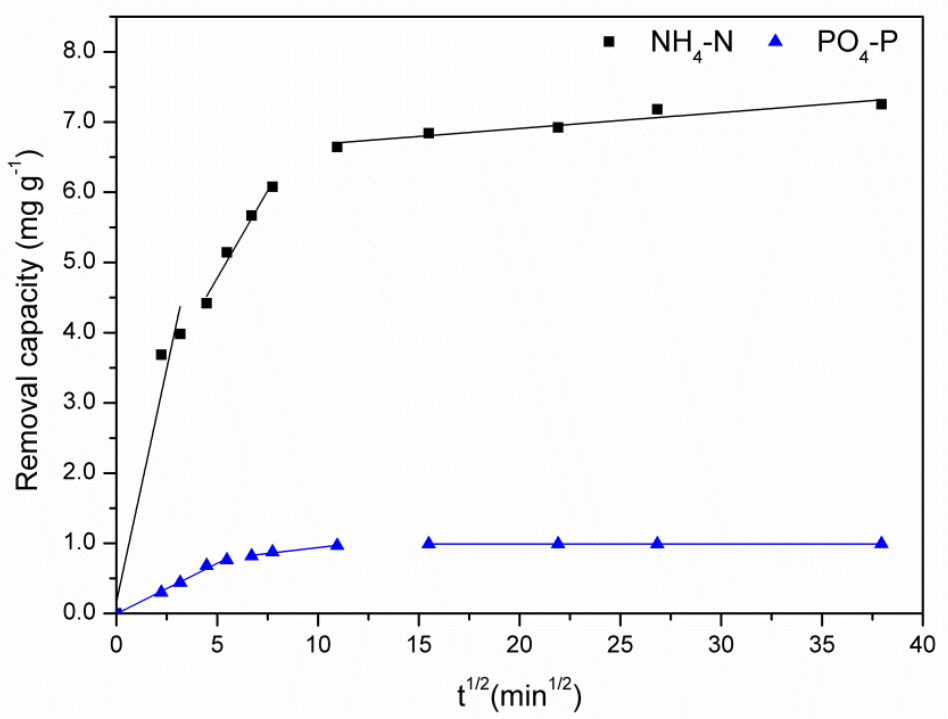

Figure 3(b). Kinetic plots of intra-particle diffusion model for ammonium and phosphate removals by the natural zeolite at initial $1000 \mathrm{mg}-\mathrm{N}^{-1}$ and $100 \mathrm{mg}^{-} \mathrm{Pl}^{-1}$ condition. 


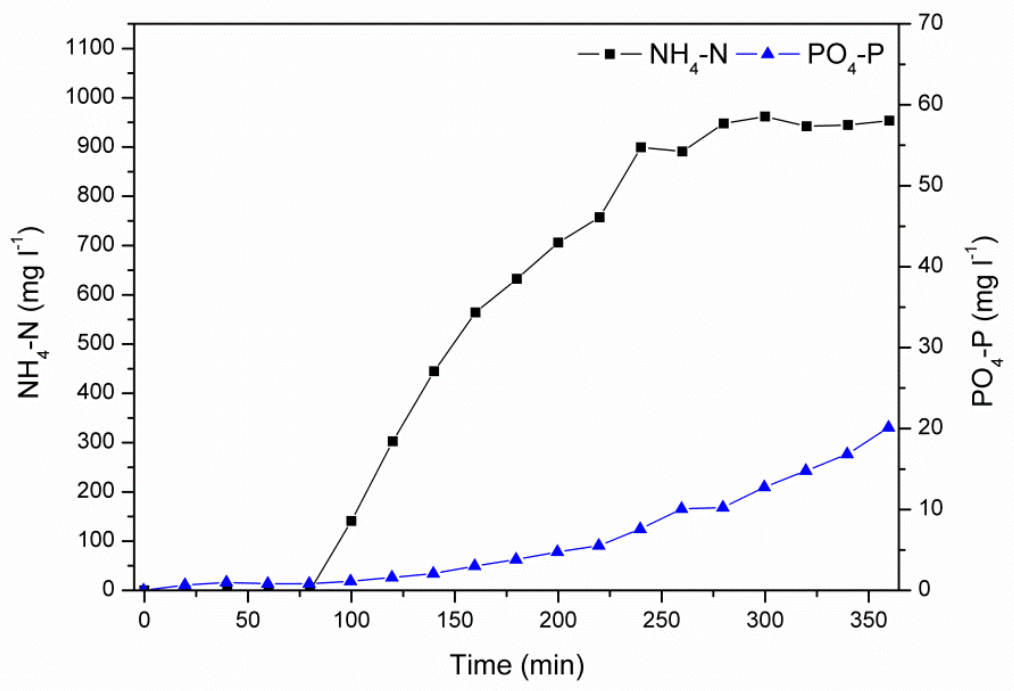

Figure 4(a). Breakthrough of ammonium and phosphate removals by the natural zeolite in column tests treating N-P mix.

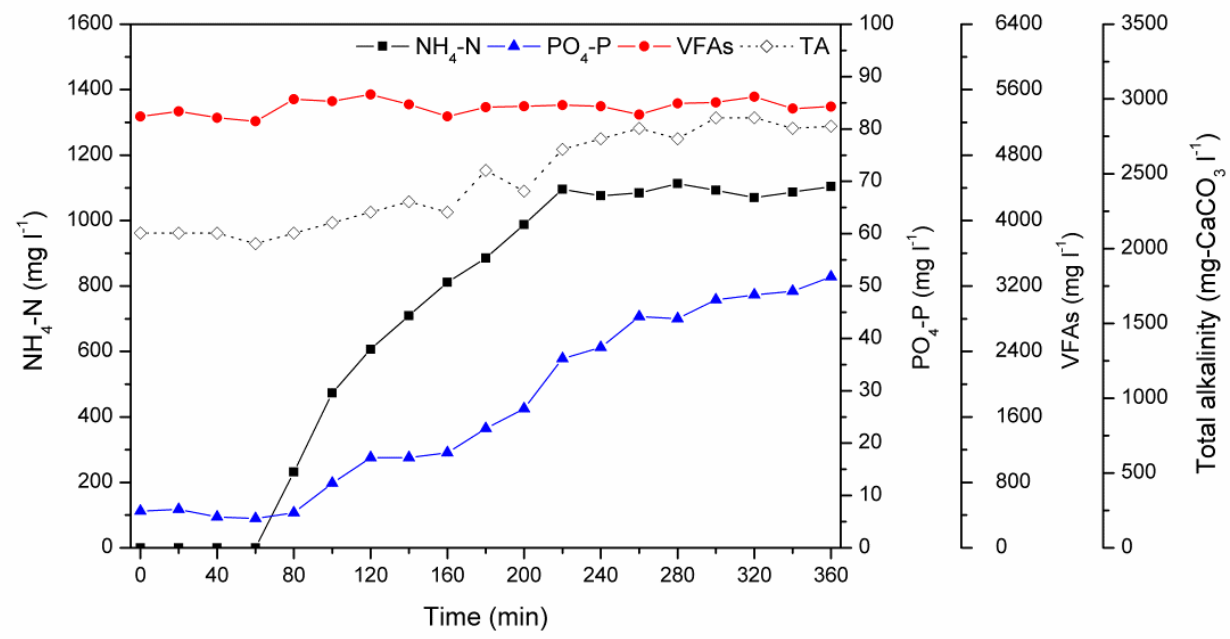

Figure 4(b). Breakthrough of ammonium, phosphate, total alkalinity and VFAs removals by the natural zeolite in column tests treating the fermentation liquor. 


\section{SUPPLEMENTARY MATERIALS}

\section{Ammonium assists orthophosphate removal from high-strength wastewaters by natural zeolite}

Lin Lin ${ }^{\mathrm{a}}$, Chunli Wan ${ }^{\mathrm{a}}$, Duu-Jong Lee ${ }^{*}, \mathrm{a}, \mathrm{c}$,, Zhongfang Lei ${ }^{\mathrm{d}}$, Xiang Liu ${ }^{\mathrm{a}}$

${ }^{a}$ Department of Environmental Science and Engineering, Fudan University, 220 Handan Road, Shanghai 200433, China

${ }^{\mathrm{b}}$ Department of Chemical Engineering, National Taiwan University of Science and Technology, Taipei 106, Taiwan

${ }^{c}$ Department of Chemical Engineering, National Taiwan University, Taipei 106, Taiwan

${ }^{\mathrm{d}}$ Graduate School of Life and Environmental Sciences, University of Tsukuba, 1-1-1 Tennodai, Tsukuba, Ibaraki 305-8572, Japan

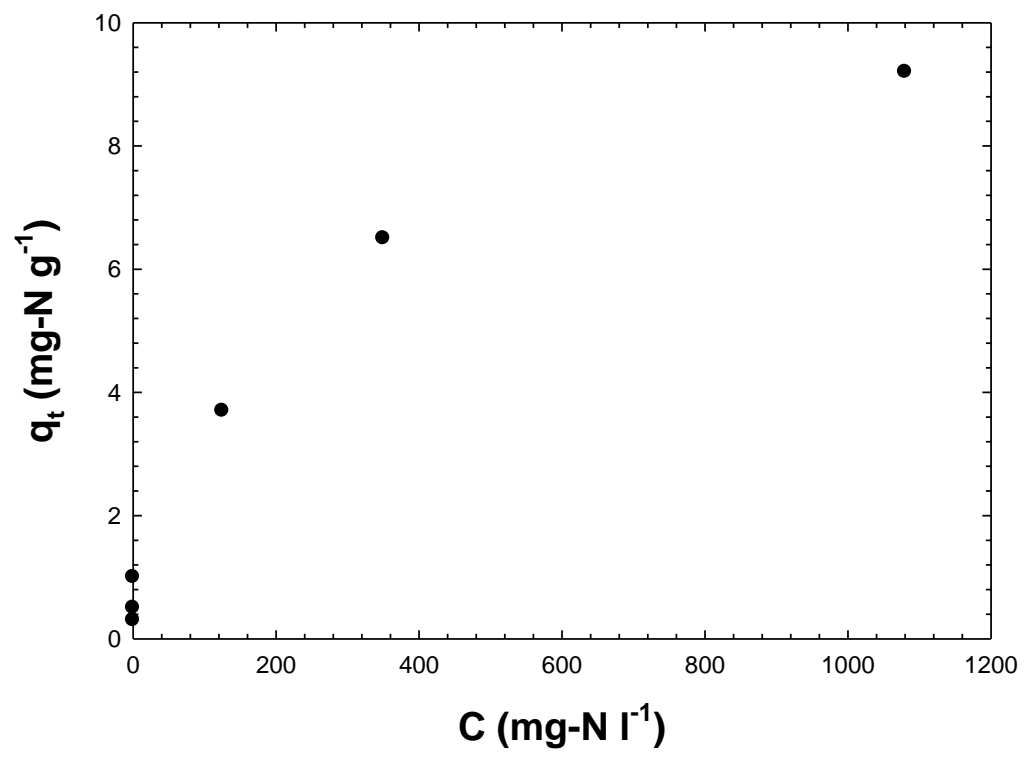

Figure S1.Adsorption isotherm $\left(\mathrm{mg} \mathrm{g}^{-1}\right.$ versus $\left.\mathrm{mg}^{-1}\right)$ of ammonium ions onto zeolite surface $\left(25^{\circ} \mathrm{C}\right)$. 


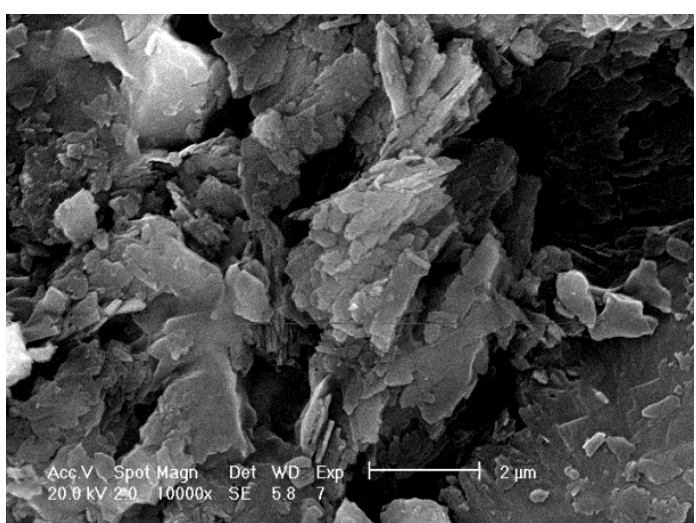

(a)

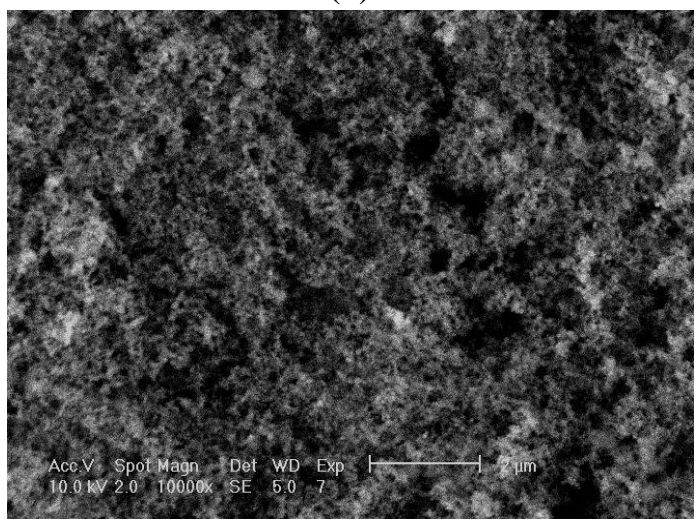

(c)

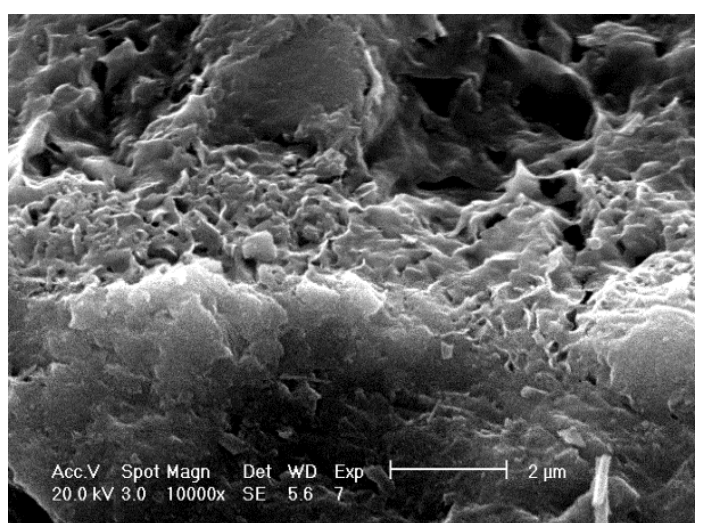

(b)

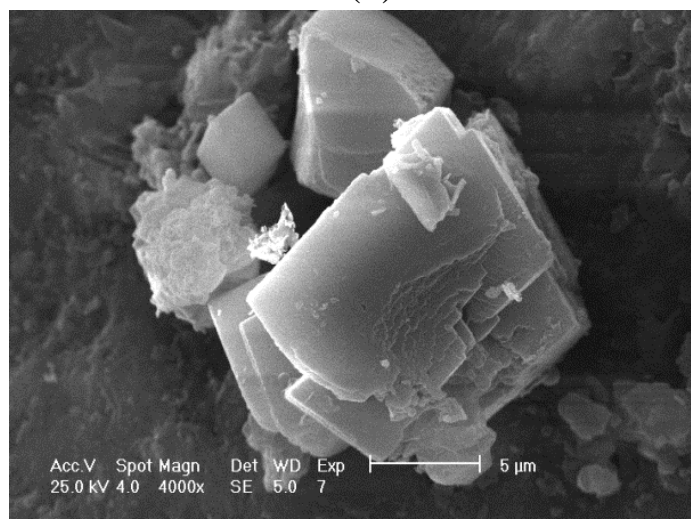

(d)

Figure S2.SEM images of the natural zeolite before adsorption (a), zeolites after treating the N-P feed solution (b), the precipitate formed in feed solution after zeolite treatment (c), and zeolites after treating the fermentation liquor $(\mathrm{d})$. 
Table S1. Testing conditions for the batch and continuous experiments.

\begin{tabular}{|c|c|c|c|c|c|c|c|}
\hline & \multirow[t]{2}{*}{ Factor } & \multicolumn{6}{|c|}{ Operational conditions } \\
\hline & & Influent type & $\begin{array}{l}\text { Initial } \\
\mathrm{NH}_{4}-\mathrm{N}\left(\mathrm{mgl}^{-1}\right)\end{array}$ & $\begin{array}{l}\text { Initial } \\
\mathrm{PO}_{4}-\mathrm{P}\left(\mathrm{mgl}^{-1}\right)\end{array}$ & $\mathrm{pH}$ & Temperature $\left({ }^{\circ} \mathrm{C}\right)$ & Time(h) \\
\hline \multirow[t]{5}{*}{ Batch } & $\mathrm{pH}$ & P solution* & 0 & 100 & $3.0-11.0$ & 25 & 24 \\
\hline & & $\begin{array}{l}\text { N-P mixed } \\
\text { solution }^{\mathrm{b}}\end{array}$ & 1000 & 100 & $3.0-11.0$ & 25 & 24 \\
\hline & $\begin{array}{l}\text { N-P } \\
\text { interaction }\end{array}$ & $\begin{array}{l}\text { N-P mixed } \\
\text { solution }\end{array}$ & $0-2000$ & 100 & 9.3 & 25 & 24 \\
\hline & & $\begin{array}{l}\text { N-P mixed } \\
\text { solution }\end{array}$ & 1000 & $0-1000$ & 9.3 & 25 & 24 \\
\hline & $\begin{array}{l}\text { Contact } \\
\text { time }\end{array}$ & $\begin{array}{l}\text { N-P mixed } \\
\text { solution }\end{array}$ & 1000 & 100 & 9.3 & 25 & $0-24$ \\
\hline \multirow[t]{2}{*}{ Column } & Feed & $\begin{array}{l}\text { N-P mixed } \\
\text { solution }\end{array}$ & 1163 & 70.4 & 9.3 & 20 & 6 \\
\hline & & $\begin{array}{l}\text { Fermentation } \\
\text { liquor }\end{array}$ & 1252 & 63.1 & 9.3 & 20 & 6 \\
\hline
\end{tabular}

* Through diluting $1000 \mathrm{mg}-\mathrm{P} \mathrm{l}^{-1}$ of sodium di-hydrogen phosphate $\left(\mathrm{NaH}_{2} \mathrm{PO}_{4}\right)$ stock solutions with deionized water 